\title{
Mesozoic-Cenozoic crustaceans preserved within echinoid tests and bivalve shells
}

\author{
ROK GAŠPARIČ, REnÉ H.B. FraAiJe, BARRY W.M. van BAKEL, JOHN W.M. JAGT \& \\ PETR SKUPIEN
}

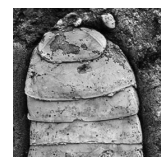

\begin{abstract}
Associations of crustaceans with echinoids (Echinodermata) and bivalves (Mollusca) are not uncommon in modern oceans. Here we record the occurrence of anomurans, brachyurans and isopods within echinoid tests and bivalve shells from the Middle Jurassic of France, the Upper Jurassic of the Czech Republic, the Eocene of Croatia and the Miocene of Austria. Additionally a new genus and species of fossil cirolanid isopod from the Middle Jurassic of France is described. The present examples are interpreted as crustacean sheltering, probably for safe and undisturbed moulting (ecdysis), within a vacant host test or shell. However, accidental association (washed in) or even food remains cannot be ruled out entirely. Key words: Crustacea, Decapoda, Isopoda, commensalism, sheltering, taphonomy.
\end{abstract}

GAŠPARIČ, R., FRAAIJE, R.H.B., VAN BAKEL, B.W.M., JAGT, J.W.M. \& SKUPIEN, P. 2015. Mesozoic-Cenozoic crustaceans preserved within echinoid tests and bivalve shells. Bulletin of Geosciences 90(3), 601-611 (4 figures). Czech Geological Survey, Prague. ISBN 1214-1119. Manuscript received January 2, 2015; accepted in revised form June 1, 2015; published online June 16, 2015; issued September 30, 2015.

Rok Gašparič (corresponding author), Oertijdmuseum De Groene Poort, Bosscheweg 80, 5293 WB Boxtel, the Netherlands; rok.gasparic@gmail.com • René H.B. Fraaije, Oertijdmuseum De Groene Poort, Bosscheweg 80, 5293 WB Boxtel, the Netherlands; info@oertijdmuseum.nl • Barry W.M. van Bakel, Oertijdmuseum De Groene Poort, Bosscheweg 80, 5293 WB Boxtel, the Netherlands; Naturalis Biodiversity Center, P.O. Box 9517, 2300 RA Leiden, the Netherlands; barryvanbakel@gmail.com•John W.M. Jagt, Natuurhistorisch Museum Maastricht, de Bosquetplein 6-7, 6211 KJ Maastricht, the Netherlands; john.jagt@maastricht.nl • Petr Skupien, Institute of Geological Engineering, V̌̌B - Technical University, 17. listopadu 15, 70833 Ostrava-Poruba, Czech Republic; petr.skupien@vsb.cz.

The association of decapod crustaceans with invertebrate hosts has been documented in detail from present-day marine environments (e.g., Morton 1989). Examples include the following. Inside the articulated shell of the pinnid bivalve Pinna rudis Linnaeus, 1758 at least one, usually two, specimens of the shrimp Pontonia pinnophylax (Otto, 1821) have been noted in the majority of individuals near Príncipe and Săo Tomé islands (Wirtz \& d'Udekem d'Acoz 2008). The number of individuals occurring inside the host appeared to be in direct correlation with the latter's size, in that smaller-sized hosts sheltered only single individuals, while larger ones were more likely to contain a pair or even a small group, consisting of a pair of adults and several juveniles.

Zullo \& Chivers (1969) recorded the pea crab Pinnixa faba (Dana, 1851) from within articulated valves of the marine bivalve Tresus capax (Gould, 1850) occurring in upper Pleistocene terrace deposits in Oregon, USA. Amongst 124 articulated shells, 27 contained either complete or fragmentary crabs. As far as we have been able to ascertain, this is the first and sole example of brachyurans preserved within bivalves that has been documented from the fossil record.

Jaramillo et al. (1981) described an association of the bivalve Mytilus chilensis Hupé, 1854 and the isopod Edotea magellanica Cunningham, 1871 from intertidal settings in southern Chile. The greatest number of isopods was noted in mussels that measured between 30 and $45 \mathrm{~mm}$ in overall length.

In the Sea of Japan the extant pinnotherid crab, Pinnotheres laquei Sakai, 1961, has been recorded from within the mantle cavity of the brachiopod Laqueus rubellus (Sowerby, 1846). Feldmann et al. (1996) were the first to provide quantitative data regarding this association. Pinnotherids are common associates of molluscs and echinoderms and tend to be host specific. The crabs appeared to be more common in larger-sized brachiopods, implying a size correlation between crab and brachiopod. No physical evidence, such as malformation of the shell or lophophore, was observed in the host brachiopods. For that reason, this association was judged to be either commensal or mutualistic, the crabs being able to enter and exit the 
mantle cavity at will. This pinnotherid/brachiopod association constitutes the only known occurrence of infestation of brachiopods by crabs in extant seas.

Recently, a small crab, Ferricorda kimberlyae (Bishop, 1987), has been discovered within part of a phragmocone of a baculitid cephalopod from the Gammon Ferruginous Member (lower Campanian) of the Pierre Shale in Butte County, South Dakota (Landman et al. 2014). The crab retains its carapace and all pereiopods, parallel to, and in between, two septa within the cephalopod shell. This enigmatic occurrence is interpreted as the first example of crab inquilinism within a heteromorph ammonite. For other examples of sheltering extinct decapod crustaceans within cephalopod shells, reference is made to Fraaye \& Jäger (1995), Fraaije \& Pennings (2006), Schulz (2002) and Klompmaker \& Fraaije (2012).

Carapaces of the raninoidean crab Necrocarcinus labeschii (Deslongchamps, 1835) have been documented within the ultimate whorls of ammonites and gastropods from the lower Cenomanian of Orne, France. Breton (2008) interpreted these as exuvia of crabs that found shelter inside the molluscan shells during ecdysis.

Several species of small-sized crabs in the sediment fill of large gastropods from the Pliocene of Belgium were illustrated and discussed by Van Bakel et al. (2004), while a complete moulted specimen of a new sand crab, Albunea turritellacola, within a large-sized turritellid gastropod from the Miocene of France was described by Fraaije et al. (2008). It would appear that empty gastropod shells are perfect places for undisturbed ecdysis for all kinds of comparatively small decapod crustaceans.

Bishop \& Portell (1989) described specimens of a new porcellanid crab, Petrolisthes myakkensis, associated with abundant asteroids, Heliaster microbrachius Xantus, 1860, from the upper Pliocene of Charlotte County, Florida, USA. The crab/asteroid association is preserved in calcareous quartzitic sandstone. The fauna is dominated by the asteroids and crabs, but barnacles are also present. Preservation as entire, fully articulated, fragile, hollow specimens preserved with articulated sea stars attests to a lack of transport. This close association, taken together with the commensal habits of other porcellanid crabs, and the commensal relationships of crabs with echinoderms lead to the conclusion that Petrolisthes myakkensis and Heliaster microbrachius were commensals.

Garth (1957) noted pinnotherids from the internal cavity of echinoids in Chilean waters, while $\mathrm{Ng} \&$ Manning (2003) recorded such crabs from inside the rectum of echinoids and holothuroids.

Only few records of extinct echinoids that preserve other organisms inside are known. Ernst (1967) described a broken test of the irregular echinoid Echinocorys with numerous bivalve and gastropod shells preserved inside, from the mid-Campanian of northwest Germany. Coeval finds, from the Hannover area (Germany), are also known and pertain to heteromorph ammonites inside micrasterid echinoids (Frerichs 2004), arcid bivalves and small-sized patelliform gastropods inside irregular echinoids (Krüger 1995a, b). Micrasterid echinoids from Turonian marls of Erwitte quarries, Münsterland, Germany, occasionally are filled with faecal pellets, possibly produced by crustaceans (pers. obs., RHBF).

Institutional abbreviations. - To indicate the repositories of specimens described here, the following abbreviations are used: MAB, Oertijdmuseum De Groene Poort, Boxtel, the Netherlands; RGM, Naturalis Biodiversity Center, Leiden, the Netherlands (formerly Rijksmuseum van Geologie en Mineralogie); RGA/SMNH, Slovenian Museum of Natural History, Ljubljana, Slovenia (R. Gašparič Collection).

\section{Isopod/bivalve association - Middle Jurassic of France}

To date, there are 62 extant genera considered valid within the family Cirolanidae (Schotte et al. 2010), and six extinct ones (e.g., Hyžný et al. 2013, Etter 2014). (Near-) complete extinct cirolanids are very rare; most frequently only the posterior part of the pereonites, together with the pleonites and pleotelson, are preserved (e.g., Quayle 1982, Feldmann et al. 1990, Karasawa et al. 1992, Fraaye \& Summesberger 1999, Feldmann \& Goolaerts 2005, Feldmann \& Rust 2006, Pasini \& Garassino 2012a-c, Hyžný et al. 2013, Jarzembowski et al. 2014). This incomplete preservation, without the cephalon and the first four pereonites, is explained by biphasic moulting (Feldmann \& Goolaerts 2005, Feldmann \& Rust 2006, Hyžný et al. 2013), in which the posterior part remains intact, while the anterior part is disarticulated and fragmentary. For this reason, most fossil isopods are represented solely by the posterior exoskeleton. In the absence of antennae, mouthparts or pereopods, it is impossible to assign extinct forms to a clearly defined extant genus (N.L. Bruce, pers. comm., June 2014). More complete fossil isopods, however, do show enough variation in their exoskeleton to be differentiated at the generic level. Hyžný et al. (2013) published a useful key for fossil cirolanid genera exclusively on the basis of posterior exoskeleton parts.

According to this key, the $31 \mathrm{~mm}$ long present specimen, preserved within a pholadomyid bivalve, is confirmed to be a cirolanid. The general shape of the exoskeleton closely resembles the extant male paratype of Cirolana diminuta Menzies, 1962 (see Brusca et al. 1995, p. 19, fig. 11B). The lateral margins of pleonites 4 and 5 are particularly prominent in dorsal view. In that character there is some resemblance to genera such as Baharilana 

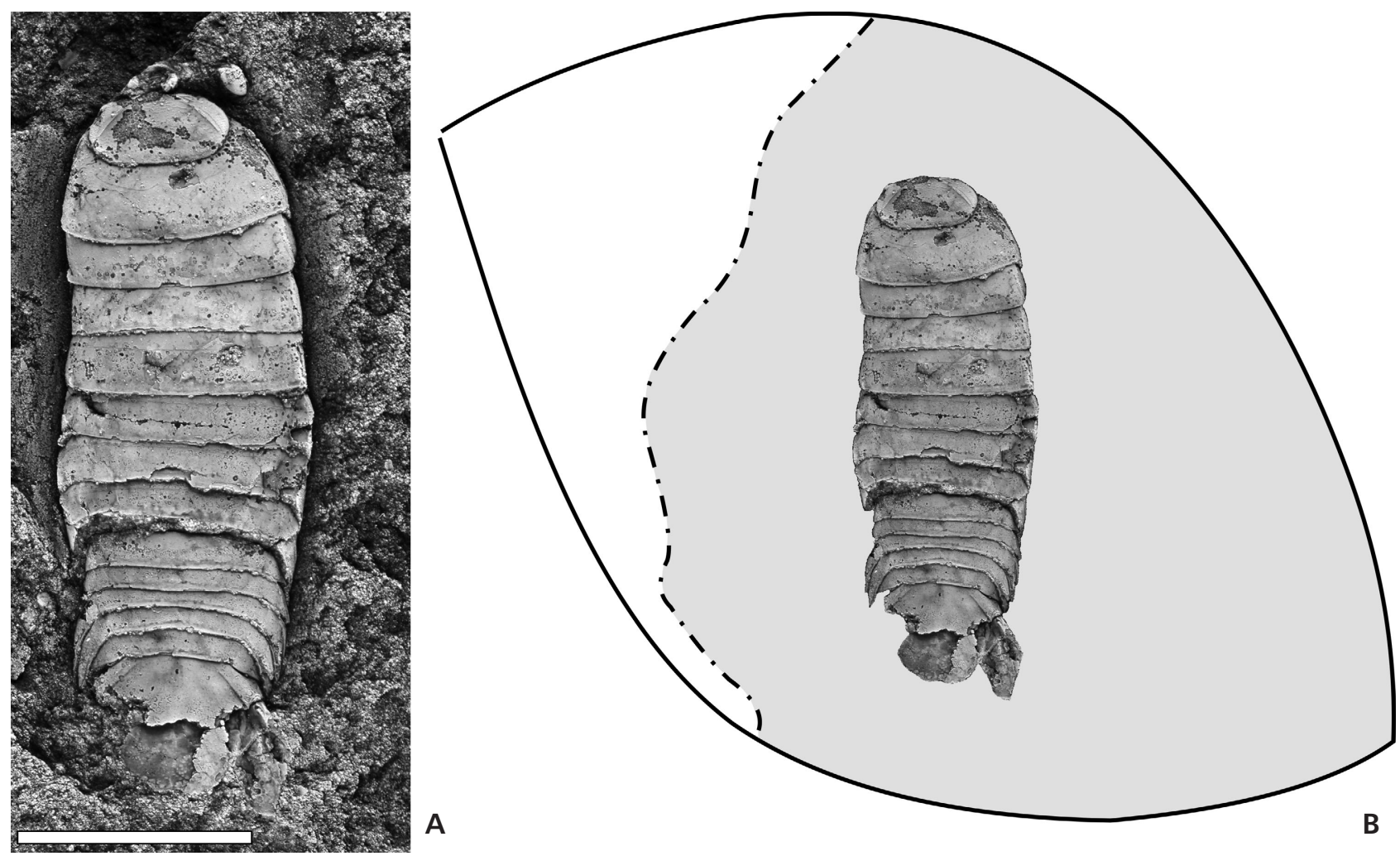

Figure 1. Pleovideolana gijsberti gen. et sp. nov., Middle Jurassic "Marnes à Pholadomya", Metz-le-Comte (Département Nièvre, central France). - A - holotype (RGM244996). Specimen whitened with ammonium chloride prior to photography. Scale bar is 10.0 mm. • B - supposed position of Pleovideolana gijsberti gen. et sp. nov. within a pholadomyid bivalve.

Bruce \& Svavarsson, 2003, Plakolana Bruce, 1993 and Aatolana Bruce, 1993. However, all fossil and extant species of Cirolana, and closely related genera, have pleonite 1 largely concealed by pereonite 7 . In the present specimen, pleonite 1 is clearly visible. In addition, a straight to slightly convex posterior border of the cephalon is uncommon. Most cirolanid genera have a concave or angular posterior cephalic border. Thus, these differences warrant the introduction of a new genus of cirolanid.

\section{Systematic palaeontology}

Order Isopoda Latreille, 1817

Suborder Cymothoida Wägele, 1989

Family Cirolanidae Dana, 1852

\section{Pleovideolana gen. nov.}

Etymology. - In allusion to the clearly visible pleonite 1 and the ending -lana used for many genera within the family Cirolanidae.

Type species. - Pleovideolana gijsberti sp. nov.
Diagnosis. - Cephalon subelliptical, with blunt rostrum; large elongated eyes bordered by slightly concave interocular carina, posteriorly almost parallel to lateral border of pereonite 1 and ending anteriorly aside rostrum; body about three times as long as wide, widest at pereonite 5-6; form of pereonites 2-4 similar to that of pereonites 5-7; pleonite 1 not concealed by pereonite 7 in dorsal view; lateral margins of pleonites 4 and 5 prominent in dorsal view; pleotelson subtriangular with anterolateral grooves and anterocentral depression, without a central keel; uropods biramous.

Discussion. - Pleovideolana gen. nov. differs from all other fossil and extant related genera, in having a combination of a non-concealed pereonite 1 by pereonite 7 and in having a straight to slightly convex posterior border of the cephalon.

Pleovideolana gijsberti sp. nov.

Figure 1A, B

Etymology. - In honour of Professor Dr Gijsbert (Bert) J. Boekschoten, who collected the holotype during a student field trip in 1977. 


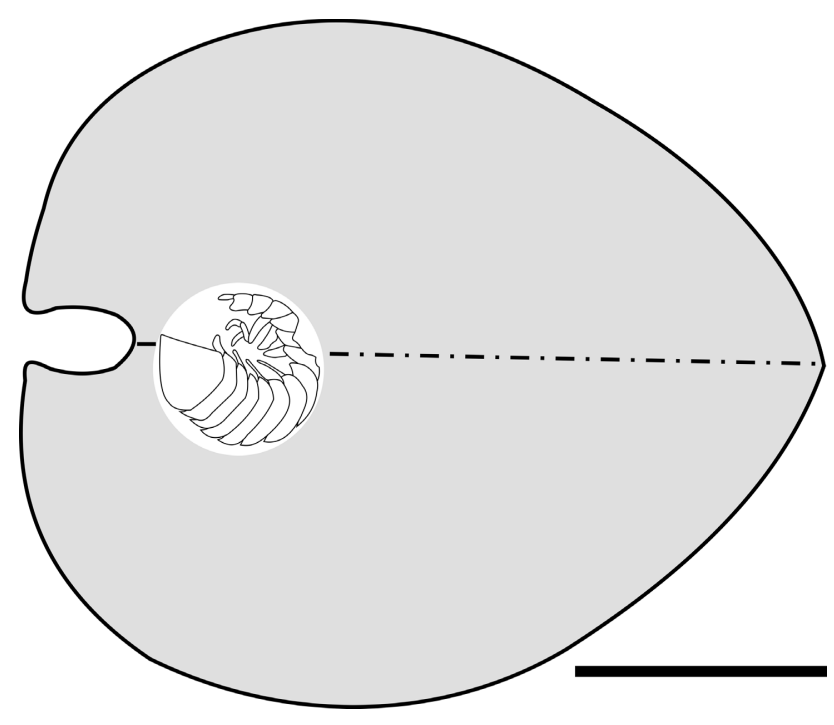

Figure 2. Stomach contents (i.e., a possibly unnamed cirolanid isopod) of an extant carnivorous poromyid bivalve, Dilemma spectralis (modified after Leal 2008). Scale bar is $5.0 \mathrm{~mm}$.

Diagnosis. - The same as for the genus.

Description. - Body elongate, lateral margins subparallel, $31 \mathrm{~mm}$ long and $11 \mathrm{~mm}$ wide $(1 / \mathrm{w}$ ratio $=2,82)$, widest at pereonite 5-6. Dorsal surface smooth, except for faint transverse marginal lines on all pereonites and faint transverse posterior marginal ridges on all pleonites. Cephalon subelliptical, length/width ratio 1:2, about two-thirds of maximum width of pereionite 1 , and ornamented with transverse crenulations. Compound eyes, anterolaterally directed, well developed and elongated, with several dozens of ommatidia, and bordered by slightly concave interocular carina, posteriorly running almost parallel to lateral border of pereonite 1 and ending anteriorly aside short, blunt rostrum. Pereonites 2-4 similar in form, with greater height/width ratio than pereonites 5-7. Pleonite 1 not concealed by pereonite 7 in dorsal view. Pleonites 3 and 4 with pointed posterolateral margins, directed posteriorly, extending beyond posterior margin of pleonite 5. Posterolateral margin of pleonite 4 clearly overlapping posterolateral margin of pleonite 5. Partially preserved pleotelson subtriangular with anterolateral grooves and anterocentral depression, lacking central keel; uropodbiramous.

Material and stratigraphy. - The holotype (RGM244996), and sole specimen known to date, was collected at a disused gravel pit a few hundred metres west of the small village of Metz-le-Comte (Département Nièvre, central France), close to the local First World War monument and opposite the Rousset Père-Fils vineyard, where the Middle Jurassic "Marnes à Pholadomya" crop out.

Remarks. - Cirolanids occur worldwide, inhabiting cool- temperate waters to tropical coral reefs. Most species have been recorded from the intertidal to depths of 1,000 metres (Bruce 2004). The majority are free-living predators or carnivorous scavengers, well capable of swimming and spending much time burrowed in sand, under rocks or in crevices. They can also be found in any suitable hiding place such as mussel beds, masses of intertidal worm tubes, kelp holdfasts or burrows of other animals (Brusca et al. 1995). Gonzalez \& Jaramillo (1991) studied associations of the clam Mulinia edulis Linnaeus, 1758 and the isopod Edotea magellanica Cunningham, 1871 on subtidal sand bars in southern Chile. The percentage of isopod occupation of bivalves in nearby estuaries varied between $1.5-4.2 \%$, while on the sand bars the ranges were $21.1-80.7 \%$. The highest percentage of isopod occupation in the clams collected from the sand bars occurred in bivalves with shell lengths ranging between 50 and $60 \mathrm{~mm}$, and isopod females outnumbered males at all localities.

Leal (2008) described a new carnivorous poromyid bivalve, Dilemma spectralis. An examination of the stomach contents of the holotype revealed a relatively intact specimen of a possibly unnamed cirolanid (Fig. 2). The stomach was greatly distended and there was no evidence of eyes, ommatidia, or pigment, which led that author to conclude that the prey item was an eyeless isopod. However, it cannot be completely ruled out the isopod was an inhabitant of the mantle cavity of the bivalve.

In the present case of Pleovideolana gijsberti gen. et sp. nov. within a pholadomyid bivalve, it is most likely that the isopod sought shelter, but it might also constitute a commensal occurrence or even stomach contents.

\section{Galatheoid/echinoid association - Late Jurassic-Early Cretaceous of the Czech Republic}

Within a nucleolitid echinoid test, of a maximum length of $38 \mathrm{~mm}$, a near-complete carapace of the galatheoid $\mathrm{Ga}$ latheites zitteli (Moericke, 1889) (maximum length $6 \mathrm{~mm}$ ) is preserved. The specimen was collected in June 2014 by one of the authors (PS) from level 5 at Kotouč quarry, Štramberk (Moravia, Czech Republic). Based on new ammonite data, the age of this specimen is the latter part of the early Tithonian (PS, pers. obs.). Traditionally, the limestones at this locality have been assumed to be of Tithonian age (Houša 1975), which may be correct for the main interval of reef development. Age estimates from calpionellid and ammonite stratigraphy, however, indicate a much longer time span, i.e., from the uppermost Kimmeridgian to the lower Berriasian for the deposition of the Stramberk Limestone (Fraaije et al. 2013). Calpionellid stratigraphy provides evidence for a latest early Tithonian to earliest Berriasian age, reaching up to the Remaniella ferasini Subzone. 


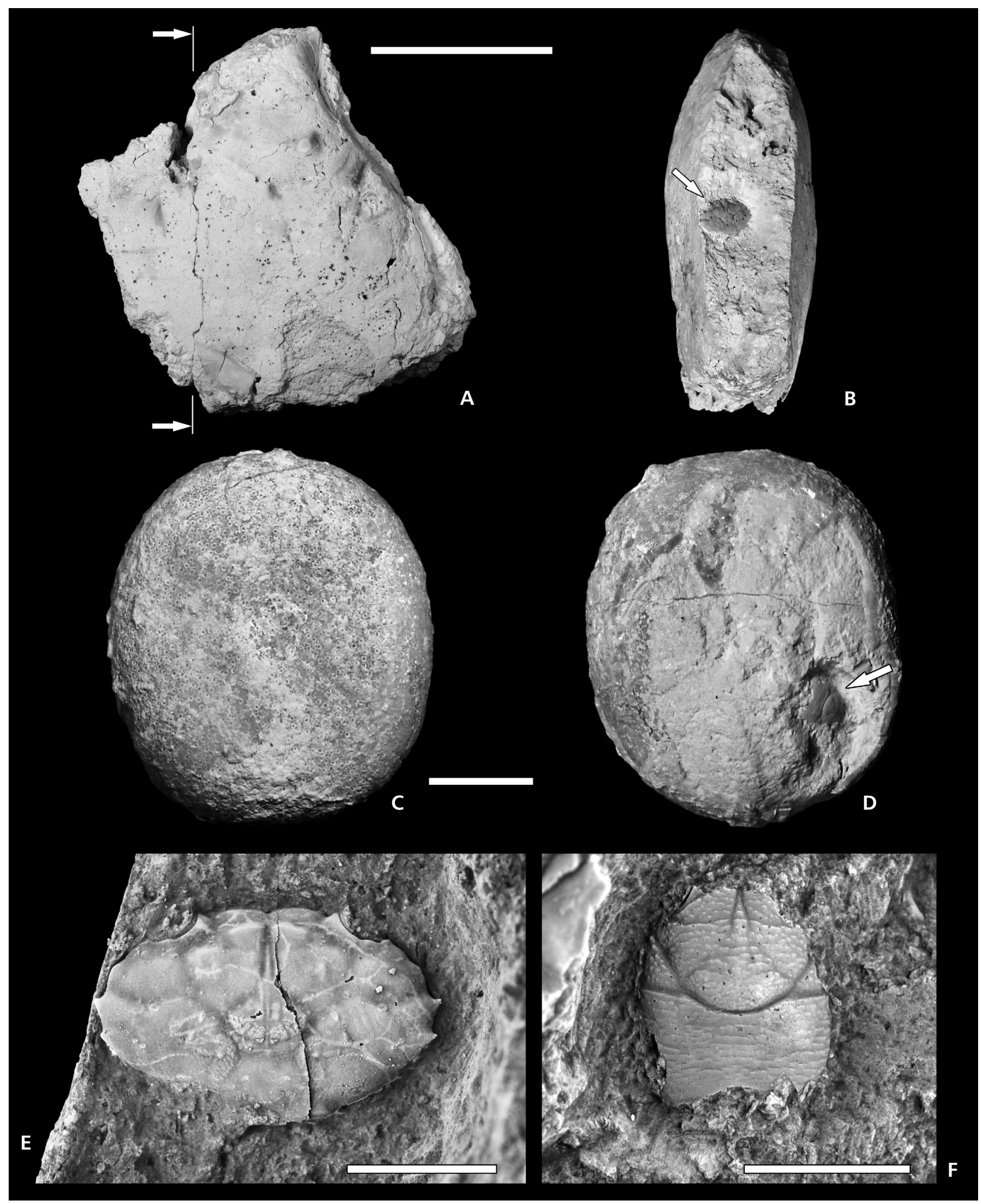

Figure 3. A, B - position of Chlorodiella tetenyensis Müller, 1984, within an articulated specimen of the bivalve Isognomon maxillatum (Lamarck, 1819), late Langhian (middle Miocene), Müllendorf quarry, eastern Austria, MAB k.3554A-B. Scale bar is 50.0 mm. • C, D - Galatheites zitteli (Moericke, 1889) within a nucleolitid echinoid test, early Tithonian, level 5 at Kotouč quarry, Štramberk (Moravia, Czech Republic), MAB k.3555A-B. Scale bar is $10.0 \mathrm{~mm}$. E - Chlorodiella tetenyensis Müller, 1984. Specimen whitened with ammonium chloride prior to photography. Scale bar is $5.0 \mathrm{~mm}$. $\bullet \mathrm{F}-$ Galatheites zitteli (Moericke, 1889). Specimen whitened with ammonium chloride prior to photography. Scale bar is $5.0 \mathrm{~mm}$. 


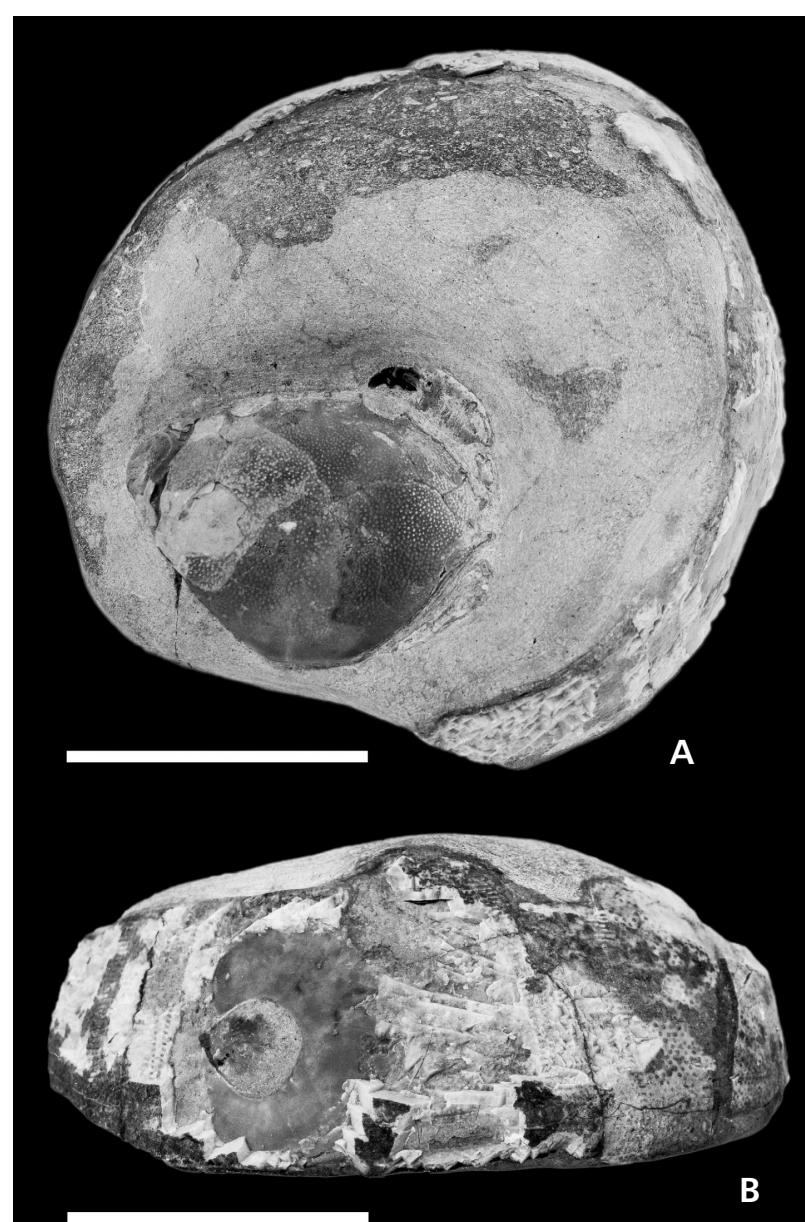

B

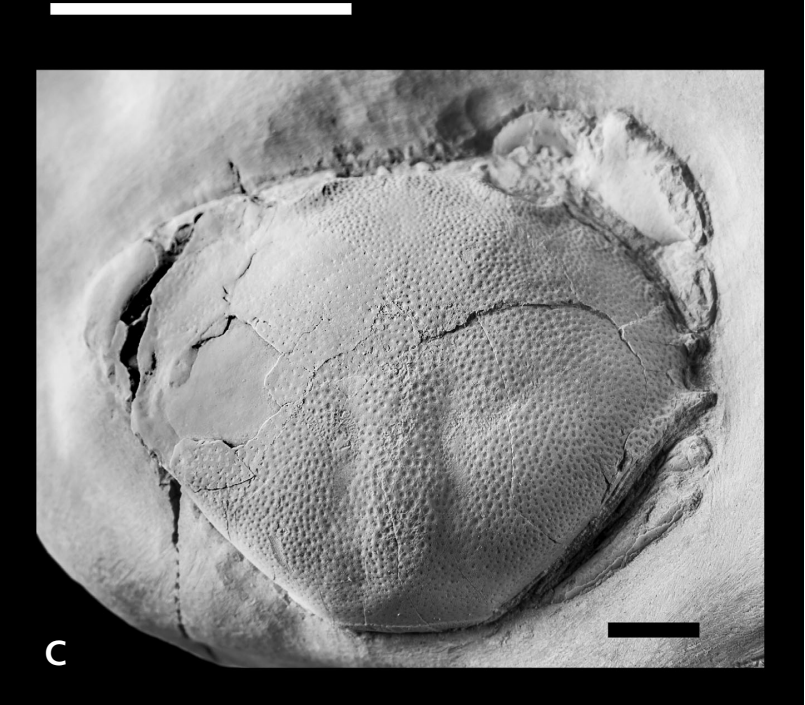

Figure 4. A - Harpactoxanthopsis quadrilobatus (Desmarest, 1822) within a test of Conoclypus conoideus (Leske, 1778), middle Eocene at Roč, Istria, Croatia, RGA/SMNH 1626. Scale bar is $50.0 \mathrm{~mm}$. - B - side view of the broken Conoclypus conoideus test, showing small epibiont oyster attachment scar. Scale bar is $50.0 \mathrm{~mm}$. $\cdot \mathrm{C}-$ articulated carapace of Harpactoxanthopsis quadrilobatus (Desmarest, 1822). Specimen whitened with ammonium chloride prior to photography. Scale bar is $10.0 \mathrm{~mm}$.
The echinoid is well preserved, with only the apical part missing (Fig. 3C, D). The relatively small galatheoid carapace lies subparallel to ambulacrum IV (see e.g., Moyne et al. 2005) with its rostrum pointing orally and its posterior margin pointing apically (Fig. 3F). The anomuran entered the test either via the damaged portion, or via the periproctal opening. In view of the small size of the test openings and the relative completeness of the carapace, this mode of preservation is interpreted as an example of sheltering, although an accidental association (i.e., washed in) cannot be ruled out completely.

\section{Echinoid/crab association - Eocene of Croatia}

Within a large test (maximum length $125 \mathrm{~mm}$ ) of Conoclypus conoideus (Leske, 1778), collected by amateur collector Mr. Tomaž Hitij from the middle Eocene at Roč, Istria, is contained a well-preserved individual of Harpactoxanthopsis quadrilobatus (Desmarest, 1822), retaining all pereiopods and both chelae. Remains of decapod crustaceans are common in Middle Eocene rocks (e.g., "marls with crabs", of Pavlovec \& Pavšič 1985) of Slovenia and Istria (Croatia), but diversity is low (Bachmayer \& Nosan 1959). All extinct decapod crustaceans on record to date from Istria are brachyurans, and the majority comprise species of the genera Harpactocarcinus A. Milne-Edwards, 1862 and Harpactoxanthopsis Via, 1959 (see Schweitzer et al. 2005). In addition, finds of the raninoidean Lophoranina are common as well (Mikuž 2003). Decapod-rich layers constitute a transitional unit, sandwiched between Nummulites limestones of the carbonate platform and the basinal flysch deposits. These beds are of middle Eocene (early Lutetian) age (Mikuž 2010), and consist of sandy to brecciated limestones, sandstones and marls. Most decapod crustacean specimens have been collected from laminated sandstones and marls, which represent a sequence of lesser water energy in the palaeoenvironment. On the other hand, tests of Conoclypus conoideus are found exclusively in brecciated and olistostrome limestones below sandstones and marls, from which only few decapod crustaceans have been recorded to date (Mikuž 2003). The present specimen originates from hard calcareous sandstone directly above the olistostrome limestone, for which a much greater energy level can be postulated. The foraminiferal and nannoplankton assemblage indicates warm water of lower salinity, which would suggest proximity of the shoreline (Pavlovec \& Pavšič 1985), and glauconitic grains in sandstones confirm the subsidence of the carbonate platform and its transition into basinal flysch sedimentation, which overlies the transitional marl beds with decapod crustaceans.

Conoclypus is characterised by a massive, oval test that commonly reaches diameters of over $100 \mathrm{~mm}$, the oral sur- 
face being flat, and the aboral side tall and conical with a sharp edge. Its reduced lantern served for feeding on algae and seaweed (Smith \& Kroh 2014). The relationship between Conoclypus and other organisms also indicates a shallow-water setting. Mitrovič-Petrovič (2002) reported several individuals of $C$. conoideus with epibiont ostreid bivalves. Oysters are shallow-water inhabitants, mostly occurring down to depths of $40 \mathrm{~m}$ and dependent of energetic waters with abundant food particles and oxygen. Many tests of $C$. conoideus exhibit fractures and mechanical damage of the aboral surface similar to the specimen illustrated here.

The abundance of broken tests of these massively tested echinoids in high-energy environment would serve as a logical natural selection of refuge for decapod crustaceans. The crab is within the echinoid (Fig. 4A), the aboral surface of which was broken. The top part of the test was broken prior to deposition and fossilisation (Fig. 4B), as demonstrated by the absence of this test portion and by the fact that the sediment within the test is level. The specimen also exhibits a small epibiont oyster attachment scar on the inside of the lateral wall of echinoid test (Fig. 4B). This supports the assumption that the test was lying broken and exposed on seabed for some time before being filled with sediment and thus presented a sturdy shelter for the crab. The $60 \mathrm{~mm}$ wide crab carapace is positioned off centre, close to the test wall; most likely, it is a corpse, rather than a moult, because it retains articulated pereiopods with chelae, the echinoid test having protected it from any post-mortem disarticulation. The carapace is wider than long, ovate and high arched, with dorsal regions poorly defined (only branchiocardiac groove is clearly seen), and its cuticular surface punctate (Fig. 4C). The front has four spines, including the inner orbital spines, while the anterolateral margin is convex, bearing five spines. The posterolateral margin is straight, the posterior margin narrow and straight as well. Chelae are strong, massive and heterochelous.

A difference in sediment fill can be observed (Fig. 4A), between calcareous sandstone inside the echinoid test. The sediment on top of the crab is softer and of a light grey colour, and that further down darker and more indurated. This could be a difference of mineralisation, or actually representation of two generations of sediment infill, with softer sandy sediment rapidly burying the crab corpse inside its refuge.

\section{Bivalve/crab association - Middle Miocene of Austria}

A carapace (maximum width $12 \mathrm{~mm}$ ) of the crab Chlorodiella tetenyensis Müller, 1984 (Fig. 3E) within an articulated specimen of the bivalve Isognomon maxillatum
(Lamarck, 1819) (Fig. 3A, B) was collected in 2006 by one of the authors (RHBF) from the lowermost accessible part of the Müllendorf quarry, eastern Austria. This part of the section exposed was characterised by a succession of Hyotissa, Isognomon and bioclastic coralline algal-molluscan facies types. The sequence at Müllendorf quarry is assigned to the Upper Lagenid and Spiroplectammina zones (see Wiedl et al. 2013, fig. 4), indicating a middle "Badenian" (= late Langhian) age for the specimen studied.

The present specimen was collected from the Isognomon facies (see Wiedl et al. 2013, fig. 2, section A), which is characterised by the common occurrence of articulated shells of Isognomon maxillatum ( $\mathrm{ca} 100 \mathrm{~mm}$ in length), often in life position, which form distinct coquinas within coralline algal rudstones with a packstone matrix. The shells usually are preserved as internal moulds (steinkerns), but occasionally remains of the calcitic shell are preserved. Coral debris (Porites spp.) occurs as well. Coralline algal macroids (diameter 5-10 mm) are common, as are some other bivalve taxa, echinoids, small gastropods and celleporiform bryozoans. Textulariid and rotaliid foraminifera are rare. In this facies, the amount of siliciclastics is low (Wiedl et al. 2013).

Being a warm-water, re-entering immigrant from the Mediterranean, Isognomon is a typical shallow-water, intertidal thermophilic, suspension-feeding epibiont. Its presence is interpreted to be indicative of a shallow subtidal setting, at a depth of 1-5 m (Harzhauser et al. 2003, Wiedl et al. 2013). The high percentage of articulated shells, often in life position and forming small biostromes, demonstrates that these concentrations are autochthonous. About twenty articulated specimens of Isognomon were broken up mechanically, yet only one contained a crab carapace. The carapace is preserved in the centre, close and perpendicular to one of the valves. Both valves have internal epibionts such as bryozoans and serpulids. This inquiline preservation could well have been the result of sediment trapping or washing in, but the completeness of the delicate carapace does not rule out that this is in fact a moult of an individual that hid in the bivalve.

The genus Chlorodiella comprises about a dozen of extant species ( $\mathrm{Ng}$ et al. 2008). All of them predominantly inhabit low intertidal to shallow subtidal coral reefs in the tropical Indo-West Pacific (Morton 1989, Davie 2002, Lasley et al. 2013). In samples of dead coral in reefs along several islands in Vietnamese seas, Chlorodiella specimens comprised more than half of all brachyurans collected, i.e., 72 species, in 32 genera and four families. The two most common species, $C$. corallicola Miyake \& Takeda, 1968 and C. laevissima (Dana, 1852), accounted for only $3 \%$ of all species, but they did represent $54 \%$ of the total number of individuals (Tan \& Thi 2007). A very similar palaeoecological and numerical occurrence for 
Chlorodiella can be postulated along the middle Miocene "Leitha Island" reefs in the Paratethys (Müller 1984).

Müller (1984, pp. 88, 89) described a subspecies, Chlorodiella mediterranea tetenyensis, but already stated that, "Though the two forms were found together, they are clearly separated. The much stronger regional definition and the very long and deep grooves along the mesogastric process, which are absent in $C$. mediterranea, warrant the new status of $C$. tetenyensis. "This interpretation is followed here, and the present form is afforded full specific status.

\section{Discussion}

At least some of the above-mentioned examples appear to represent cases in which crustaceans selected empty and dead shell of host organisms, most likely seeking shelter. Similar behaviour can be observed in the extant cancrid crab, Cancer magister (Dana, 1852). Juveniles of the species seek a sheltered mode of living among clams, Mya arenaria Linnaeus, 1758, and oysters Crassostrea gigas (Thunberg, 1793) in the first months of their benthic life (Fernandez et al. 1993). Crabs actively select a habitat which provides the lowest risk of mortality by predation during vulnerable times, and move out to subtidal mudflats after reaching size of $>35 \mathrm{~mm}$ when they are able to avoid most predators on account of their greater size. Although this example is given for the larval to juvenile stages of crab life, which tends to have highest mortality rate (Wilson et al. 1990), the same modus operandi can be stipulated for moulting, which is a time when adult crustaceans are most vulnerable. It would be reasonable to assume that individuals at time of moulting would seek shelter in empty shells of bivalves and echinoids like they did in ammonite and nautiloid shells (e.g., Fraaije \& Jäger 1995, Fraaije \& Pennings 2006, Klompmaker \& Fraaije 2012, Landman $e t$ al. 2014). Another possible explanation for habitat selection within empty shells would be to lie in hiding for hunting and preying upon passing prey.

The octopus Amphioctopus marginatus (Taki, 1964) preys on crabs from a lair, which usually is in between the valves of a bivalve (Finn et al. 2009). If small octopids used empty bivalves for a lair already in the Miocene, the carapace within Isognomon from Müllendorf quarry, Austria could also present the remains of such an octopod dinner.

\section{Conclusions}

The presented associations represent evidence of sheltering behavior of crustaceans in Mesozoic-Cenozoic environments. The importance of such refuge, especially during moulting, is highlighted in isopod/bivalve association from middle Jurassic of France, where a delicate, nearly complete extinct cirolanid Pleovideolana gijsberti gen. et sp. nov. is described for the first time.

We present three further associations from high-energy environments, which would necessitate additional protection of crustaceans during vulnerable time of moulting. This is supported by the corresponding palaeoecological data, which points to high-energy reefal, intertidal and shallow-marine environments. Such turbulent waters would be unfavorable to freshly moulted individuals, which would find refuge inside sturdy structures of robust intertidal invertebrates. Although such examples from the fossil record are rare, we postulate that this mode of preservation probably is a commoner phenomenon in comparison to extant biotic associations in the sea.

\section{Acknowledgements}

We thank Natasha den Ouden (Naturalis Biodiversity Center, Leiden) for the loan of the isopod specimen, Günter Schweigert (Staatliches Museum für Naturkunde, Stuttgart) for supply of literature, Oleg Mandic (Naturhistorisches Museum Wien, Vienna) for identifying the Miocene bivalve, Neil L. Bruce (Museum of Tropical Queensland, Brisbane) for offering support in our interpretation of the new isopod, and Cristina Robins (Florida Museum of Natural History, University of Florida) for assistance in identifying the galatheoid from Štramberk. We are especially grateful to Michał Rakociński (University of Silesia, Faculty of Earth Sciences, Poland) and Adiël A. Klompmaker (Florida Museum of Natural History, University of Florida) for their careful reviews and constructive suggestions.

\section{References}

BACHMAYer, F. \& NosAn, A. 1959. Ein bemerkenswerter Crustaceenfund aus Gračišče bei Kubed (Nordistrien). Geologija 5, $80-85$.

BALss, H. 1913. Über fossile Galatheiden. Centralblatt für Mineralogie, Geologie und Paläontologie 1913, 155-160.

Bishop, G.A. 1987. Dromiopsis kimberlyae: a new Late Cretaceous crab from the Pierre Shale of South Dakota. Proceedings of the Biological Society of Washington 100, 35-39.

Bishop, G.A. \& Portell, R.W. 1989. Pliocene crab-sea star association from southwest Florida, USA. Journal of Crustacean Biology 9, 453-458. DOI 10.2307/1548570

BRETON, G. 2008. Une carapace de crabe préservée dans le moule interne d'un gastropode du Cénomanien de Basse-Normandie (France). L'Écho des Falaises 12, 51-57.

BRUCE, N.L. 1993. Two new genera of marine isopod crustaceans (Cirolanidae) from Madang, Papua New Guinea. Memoirs of the Queensland Museum 31, 1-15.

BruCE, N.L. 2004. New species of the Cirolana "parva-group" (Crustacea: Isopoda: Cirolanidae) from coastal habitats around New Zealand. Species Diversity 9, 47-66. 
Bruce, N.L. \& Svavarsson, J. 2003. A new genus and species of cirolanid isopod (Crustacea) from Zanzibar, Tanzania, western Indian Ocean. Cahiers de Biologie Marine 44, 1-12.

Brusca, R.C., Wetzer, R. \& France, S.C. 1995. Cirolanidae (Crustacea: Isopoda: Flabellifera) of the tropic eastern Pacific. Proceedings of the San Diego Natural History 30, 1-96.

Cunningham, R.O. 1871. Notes on the reptiles, Amphibia, fishes, Mollusca, and Crustacea obtained during the voyage of H.M.S. 'Nassau' in the years 1866-69. Transactions of the Linnaean Society of London 27, 465-502. DOI 10.1111/j.1096-3642.1871.tb00219.x

DANA, J.D. 1851. On the classification of the Cancroidea, III. Zoology. Scientific Intelligence, American Journal of Science and Arts (2)12(34), 121-131.

DANA, J.D. 1852. Crustacea. United States Exploring Expeditions during the years 1838, 1839, 1840, 1841, 1842 under the command of Charles Wilkes, U.S.N. 13, 1-685. Philadelphia, C. Sherman.

DAvie, P.J.F. 2002. Crustacea: Malacostraca. Eucarida (Part 2). Decapoda-Anomura, Brachyura. Zoological Catalogue of Australia, 19.3B, CSIRO Publications, 1-641.

Deslongchamps, E. [Eudes-], J.-A. 1835. Mémoire pour servir à l'histoire naturelle des crustacés fossiles. Mémoires de la Société linnéenne de Normandie 5, 37-41.

Desmarest, A.G. 1822. Les crustacés proprement dits, 67-142. In Brongniart, A. \& Desmarest, A.G. (eds) Histoire naturelle des crustacés fossiles, sous les rapports zoologiques et géologiques. F.-G. Levrault, Paris.

ERnst, G. 1967. Über Fossilnester in Pachydiscus-Gehäusen und das Lagenvorkommen von Echiniden in der Oberkreide NW-Deutschlands. Paläontologische Zeitschrift 41, 211-229. DOI 10.1007/BF02988124

ETTER, W. 2014. A well-preserved isopod from the Middle Jurassic of southern Germany and implications for the isopod fossil record. Palaeontology 57, 931-949. DOI 10.1111/pala.12095

Feldmann, R.M. \& GoolaerTs, S. 2005. Palaega rugosa, a new species of fossil isopod (Crustacea) from Maastrichtian rocks of Tunisia. Journal of Paleontology 79, 1031-1035. DOI 10.1666/0022-3360(2005)079[1031:PRANSO]2.0.CO;2

Feldmann, R.M., JaGT, J.W.M. \& Tshudy, D.M. 1990. Late Maastrichtian isopod and decapod Crustacea from Haccourt, northeastern Belgium. Mededelingen Rijks Geologische Dienst 44, 23-35.

Feldmann, R.M., MacKinnon, D.I., Endo, K. \& ChirinoGÁlveZ, L. 1996. Pinnotheres laquei Sakai (Decapoda: Pinnotheridae), a tiny crab commensal within the brachiopod Laqueus rubellus (Sowerby) (Terebratulida: Laqueidae). Journal of Paleontology 70, 303-311.

Feldmann, R.M. \& Rust, S. 2006. Palaega kakatahi n. sp.: the first record of a marine isopod from the Pliocene of New Zealand. New Zealand Journal of Geology and Geophysics 49, 411-415. DOI 10.1080/00288306.2006.9515177

Fernandez, M., Iribarne, O. \& ARMstrong, D. 1993. Habitat selection by young-of-the-year Dungeness crab Cancer magister and predation risk in intertidal habitats. Marine Ecology Progress Series 92, 171-177. DOI 10.3354/meps092171

Finn, J.K., TregenZa, T. \& Norman, M.D. 2009. Defensive tool use in a coconut-carrying octopus. Current Biology 19, 1069-1070. DOI 10.1016/j.cub.2009.10.052
FraaiJe, R.H.B. \& Pennings, H.W.J. 2006. Crab carapaces preserved in nautiloid shells from the Upper Paleocene of Huesca (Pyrenees, Spain). Revista Mexicana de Ciencias Geológicos 23, 361-363.

FraAiJe, R.H.B., VAn BaKel, B.W.M. \& JAGT, J.W.M. 2008. Albunea turritellacola, a new sand crab (Anomura, Albuneidae) from the lower Miocene of southwest France. Bulletin of the Mizunami Fossil Museum 34, 17-22.

Fraaije, R.H.B., Van Bakel, B.W.M., Jagt, J.W.M. \& Skupien, P. 2013. First record of paguroid anomurans (Crustacea) from the Tithonian-lower Berriasian of Stramberk, Moravia (Czech Republic). Neues Jahrbuch für Geologie und Paläontologie Abhandlungen 269, 251-259. DOI 10.1127/0077-7749/2013/0348

FrAAYE, R.H.B. \& JÄGER, M. 1995. Decapods in ammonite shells: examples of inquilinism from the Jurassic of England and Germany. Palaeontology 38, 63-75.

FraAye, R.H.B. \& Summesberger, H. 1999. New crustacean records from the Late Campanian of Austria. Beiträge zur Paläontologie 24, 1-6.

Frerichs, U. 2004. Besondere Seeigel aus der Oberkreide von Hannover, Teil 8: Micraster mit Ammoniten-Steinkern. Arbeitskreis Paläontologie Hannover 32, 82-83.

GARTH, J.S. 1957. The Crustacea Decapoda Brachyura of Chile. Reports of the Lund University Chile Expedition 1948-1949 $29,3-125$.

GonZALEZ, M. \& JARAmillo, E. 1991. The association between Mulinia edulis (Mollusca, Bivalvia) and Edotea magellanica (Crustacea, lsopoda) in southern Chile. Revista Chilena de Historia Natural 64, 37-51.

Gould, A. 1850. Shells from the U.S. Exploring Expedition. Proceedings of the Boston Society of Natural History 3, 214-218.

Harzhauser, M., Mandic, O. \& Zuschin, M. 2003. Changes in Paratethyan marine molluscs at the Early/Middle Miocene transition: diversity, paleogeography and paleoclimate. Acta Geologica Polonica 53, 323-339.

HoušA, V. 1975. Geology and paleontology of the Stramberg Limestone (upper Tithonian) and the associated lower Cretaceous beds. Mémoires du Bureau de Recherches Géologiques et Minières 86, 342-349.

Hupé, L. 1854. Moluscos de Chile, 1-500. In GAY, C. (ed.) Historia física y política de Chile, Zoologia 8.

HyŽNÝ, M., BRUCE, N.L. \& SCHLÖGL, J. 2013. An appraisal of the fossil record for the Cirolanidae (Malacostraca: Peracarida: Isopoda: Cymothoida), with a description of a new cirolanid isopod crustacean from the Early Miocene of the Vienna Basin (Western Carpathians). Palaeontology 56, 615-630. DOI 10.1111/pala.12006

JARAmillo, E., NAVARro, J. \& Winter, J. 1981. The association between Mytilus chilensis Hupé (Bivalvia, Mytilidae) and Edotea magellanica Cunningham (Isopoda, Valvifera) in southern Chile. Biological Bulletin 160, 107-113. DOI 10.2307/1540904

JarZembowski, E.A., WANG, B., FAnG, Y. \& Zhang, H. 2014. A new aquatic crustacean (Isopoda: Cymothoida) from the early Cretaceous of southern England and comparison with the Chinese and Iberian biotas. Proceedings of the Geologists' Association 125, 446-451.

Karasawa, H., Nobuhara, T. \& Matsuoka, K. 1992. Fossil and 
living species of the giant isopod genus Palaega Woodward, 1870 of Japan. Science Reports of the Toyohashi Museum of Natural History 2, 1-12.

Klompmaker, A.A. \& FraaiJe, R.H.B. 2012. Animal behavior frozen in time: gregarious behavior of Early Jurassic lobsters within an ammonoid body chamber. PLOS ONE 7(3), e31893. DOI 10.1371/journal.pone.0031893

KRÜGER, F.J. 1995a. Leere oberkretazische Echiniden-Coronen als Habitat benthonischer Organismen, 79-89. In KOHRING, R. \& Wilmsen, M. (eds) Miscellanea Palaeontologica 4. Gundolf-Ernst-Festschrift. Berliner geowissenschaftliche Abhandlungen E16.

KRÜGER, F.J., 1995b. Zwangshabitate von Mollusken in leeren Seeigel-Coronen aus dem Campan von Höver und Misburg. Arbeitskreis Paläontologie Hannover 23, 31-40.

LAMARCK, J.-B. M. de. 1819. Histoire naturelle des animaux sans vertèbres 6(1), i-vi + 1-343. Déterville, Paris.

Landman, N.H., FraAije, R.H.B., KlofaK, S.M., Larson, N.L., BISHOP, G.A. \& KRUTA, I. 2014. Inquilinism of a baculite by a dynomenid crab from the Upper Cretaceous of South Dakota, USA. American Museum Novitates 3818, 1-16.

DOI $10.1206 / 3818.1$

LASLEY, JR., R.M., LaI, J.A.C. \& THOMA, B.P. 2013. A new genus for Chlorodiella longimana (H. Milne Edwards) supported by morphology and molecular data, with a preliminary phylogeny of the Chlorodiellinae (Crustacea: Decapoda: Xanthidae). Invertebrate Systematics 27, 379-390. DOI 10.1071/IS12075

LATREILLE, P.A. 1817. Les crustacés, les arachnides, les insectes, 1-653. In CuvieR, G. Le règne animal distribué d'après son organisation, pour servir de base à l'histoire naturelle des animaux et d'introduction à l'anatomie comparée. Aves figures, dessinées d'après nature 3. Déterville, Paris.

LEAL, J.H. 2008. A remarkable new genus of carnivorous, sessile bivalves (Mollusca: Anomalodesmata: Poromyidae) with descriptions of two new species. Zootaxa 1764, 1-18.

LESKE, N.G. 1778. Jacobi Theodori Klein Naturalis dispositio Echinodermatum. 278 pp. G.E. Beer, Leipzig.

LinNAeus, C. 1758. Systema naturae per regna tria naturae: secundum classes, ordines, genera, species, cum characteribus, differentiis, synonymis, locis. 824 pp. Laurentius Salvius, Stockholm.

Menzies, R.J. 1962. The marine isopod fauna of Bahía de San Quintin, Baja California, Mexico. Pacific Naturalist 3, 337-348.

MikUŽ, V. 2003. Lophoranina marestiana from Middle Eocene flysch beds at Gracisce, Istria, Croatia. Geologija 47, 23-27. DOI 10.5474/geologija.2004.002

MıKUŽ, V. 2010. Ostanek eocenske rakovice iz kamnoloma Griža. Folia biologica et geologica 51, 21-26.

Milne-EdwardS, A. 1862. Monographie des crustacés fossiles de la famille des Cancériens. Annales des sciences naturelles, Zoologie, Série 4, 18, 31-85.

Mitrovič-Petrovič, J. 2002. Paleoecological features and stratigraphic significance of the genus Conoclypus (Echinoidea). Annales Géologiques de la Péninsule Balkanique 64, 89-105. DOI 10.2298/GABP0264089M

MiyaKe, S. \& TAKedA, M. 1968. Two new species of xanthid crabs from the Palau Islands. Journal of the Faculty of Agriculture, Kyushu University 14, 389-398.
Moericke, E. 1889. Crustaceen der Stramberger Schichten. Palaeontographica 2, 43-72.

Moyne, S., Thierry, J., Marchand, D., Nicolleau, P., Pineau, P., Courville, P. \& SAucĖde, T. 2005. Le genre Nucleolites (Echinoidea, Cassiduloidea) du Bajocien à l'Oxfordien dans le Bassin de Paris: apport des données architecturales à la systématique et à la phylogénie. Geobios 38, 519-532. DOI 10.1016/j.geobios.2003.12.005

Morton, B. 1989. Partnerships in the sea; Hong Kong's marine symbiosis. 124 pp. Hong Kong University Press, Hong Kong.

MüLlER, P. 1984. Decapod Crustacea of the Badenian. Geologica Hungarica, Series Palaeontologica 42, 3-317.

NG, P.K.L., Guinot, D. \& Davie, P.J.F. 2008. Systema Brachyurorum, Part I. An annotated checklist of extant brachyuran crabs of the world. Raffles Bulletin of Zoology, Supplement 17, 1-286.

NG, P.K.L. \& MAnning, R.B. 2003. On two new genera of pea crabs parasitic in holothurians (Crustacea: Decapoda: Brachyura: Pinnotheridae) from the Indo-West Pacific, with notes on allied genera. Proceedings of the Biological Society of Washington 116, 901-919.

Отто, A.G. 1821. Animalium maritimorum nondum editorum genera duo. Nova Acta physico-medica Academiae Caesareae Leopoldino-Carolinae Naturae Curiosorum 10, 617-634.

Pasini, G. \& Garassino, A. 2012a. Palaega pisana n. sp. (Crustacea, Isopoda, Cirolanidae) from the Pliocene of Orciano Pisano, Pisa (Toscana, Central Italy). Atti della Società Italiana di Scienze Naturali e del Museo Civico di Storia Naturale in Milano 153, 3-11.

DOI $10.4081 /$ nhs. 2012.3

Pasini, G. \& Garassino, A. 2012b. First record of cirolanids (Crustacea, Isopoda, Cirolanidae) from the Middle Pliocene of Parma and Reggio Emilia Province (Emilia Rornagna, N Italy). Atti della Società Italiana di Scienze Naturali e del Museo Civico di Storia Naturale in Milano 153, 13-20.

DOI 10.4081/nhs.2012.13

Pasini, G. \& Garassino, A. 2012c. Palaega picena n. sp. (Crustacea, Isopoda, Cirolanidae) from the Miocene of Árcevia, Ancona (Marche, Central Italy). Atti della Società Italiana di Scienze Naturali e del Museo Civico di Storia Naturale in Milano 153, 21-26. DOI 10.4081/nhs.2012.21

PAVloveC, R. \& PAVŠIČ, J. 1985. Biostratigrafija plasti z rakovicami v Istri. Geologija 28/29, 55-68.

QuAYLE, W.J. 1982. A new Eocene isopod (Crustacea) from the Hampshire Basin. Tertiary Research 4, 31-34.

SAKAI, T. 1961. New species of Japanese crabs from the collection of his Majesty the Emperor of Japan. Crustaceana 3, 131-150. DOI 10.1163/156854061X00635

Schotte, M., Boyko, C.B., Bruce, N.L., Markham, J., Poore, G.C.B., TAITI, S. \& Wilson, G.D.F. 2010. World list of marine, freshwater and terrestrial isopods.

http://www.marinespecies.org/Isopoda/index.php

Schulz, M. 2002. Krebse aus dem Oberen Muschelkalk von Osthessen und Thüringen, 1. Pseudopemphix alberti (H. v. Meyer, 1840). Veröffentlichungen aus dem Naturkundemuseum Erfurt 21, 15-38.

Schweitzer, C.E., Ćosović, V. \& Feldmann, R.M. 2005. Harpactocarcinus from the Eocene of Istria, Croatia, and the paleoecology of the Zanthopsidae Via, 1959 (Crustacea: 
Decapoda: Brachyura). Journal of Paleontology 79, 663-669. DOI 10.1666/0022-3360(2005)079[0663:HFTEOI]2.0.CO;2

Sмith, A.B. \& KRoH, A. (eds) 2011. The Echinoid Directory. http://www.nhm.ac.uk/research-curation/projects/echinoid -directory [accessed 25 December 2014]

Sowerby, G.B. 1846. Descriptions of thirteen new species of brachiopods. Proceedings of the Zoological Society of London 14, 91-95.

TAKI, I. 1964. On eleven new species of the Cephalopoda from Japan, including two new genera of the Octopodinae. Journal of the Faculty of Fisheries and Animal Husbandry, Hiroshima University 5, 297-343.

TAN, H.D. \& THI, D.P. 2007. Species composition and diversity of xanthoid crabs (Decapoda: Xanthoidea) among dead corals in Nhatrang Bay, south central Vietnam. Publications of the Seto Marine Biological Laboratory, Special Publication (8)8, $87-95$.

ThunBerg, C.P. 1793. Tekning och Beskrifning på en stor Ostronsort ifrån Japan. Kongliga Vetenskaps-Akademiens Nya Handlingar 14, 140-142.

Van Bakel, B.W.M., Jagt, J.W.M., FraAiJe, R.H.B. \& Wille, E.R.H. 2004. Piacenzian (Pliocene) decapod crustacean faunules from northwest Belgium. Bulletin of the Mizunami Fossil Museum 30 (for 2003), 97-108.
VIA, L. 1959. Decápodos fósiles del Eoceno español. Boletín del Instituto Geológico y Minero de España 70, 331-402.

WäGELE, J.W. 1989. Evolution und phylogenetisches System der Isopoda. Zoologica 132, 12-62.

Wiedl, T., Harzhauser, M., Kroh, A., Corić, S. \& Piller, W.E. 2013. Ecospace variability along a carbonate platform at the northern boundary of the Miocene reef belt (Upper Langhian, Austria). Palaeogeography, Palaeoclimatology, Palaeoecology 370, 232-246.

DOI 10.1016/j.palaeo.2012.12.015

Wilson, K.A., Able, K.W. \& Heck, K.L. 1990. Predation rates on juvenile blue crabs in estuarine nursery habitats: evidence for the importance of macroalgae (Ulva lactuca). Marine Ecology Progress Series 58, 243-258.

DOI $10.3354 /$ meps 058243

Wirtz, P. \& D'Udekem D'Acoz, C. 2008. Crustaceans associated with Cnidaria, Bivalvia, Echinoidea and Pisces at São Tomé and Príncipe islands. Arquipélago 25, 63-69.

Xantus, J. 1860. Description of three new species of starfish from Cape St. Lucas. Proceedings of the Academy of Natural Sciences in Philadelphia 1860, 568.

Zullo, V.A. \& Chivers, D.D. 1969. Pleistocene symbiosis: pinnotherid crabs in pelecypods from Cape Blanco, Oregon. The Veliger 12, 72-73. 